Short Communication

\title{
The MERSADE (European Union) project: Testing procedures and environmental impact for the safe storage of liquid mercury in the Almadén district, Spain
}

\author{
W. Llanos ${ }^{\text {a,b }}$, P. Higueras ${ }^{\text {a,* }}{ }^{\text {, R. Oyarzun }}{ }^{\text {b }}$, J.M. Esbrí a ${ }^{\text {, M.A. López-Berdonces }}{ }^{\text {a }}$, \\ E.M. García-Noguero ${ }^{a}$, A. Martínez-Coronado ${ }^{\text {a,b }}$ \\ a Departamento de Ingeniería Geológica y Minera, Escuela Universitaria Politécnica de Almadén, Universidad de Castilla-La Mancha, Plaza M. Meca 1, 13400 Almadén, Spain \\ b Departamento de Cristalografía y Mineralogía, Facultad de Ciencias Geológicas, Universidad Complutense, 28040 Madrid, Spain
}

\section{A R T I C L E I N F O}

\section{Article history:}

Received 23 December 2009

Received in revised form 12 May 2010

Accepted 14 May 2010

Available online 2 July 2010

\section{Keywords:}

Almadén district

Las Cuevas

Spain

Mercury safe deposit

Baseline

\begin{abstract}
A B S T R A C T
The MERSADE Project (LIFE - European Union) tested the Las Cuevas decommissioned mining complex (Almadén mercury district, Spain) as a potential site for the installation of a future European prototype safe deposit of surplus mercury from industrial activities. We here present the results of a baseline study on the distribution of mercury in soils and air in the Las Cuevas complex and surrounding areas, and show the results of a plume contamination model using the ISC-AERMOD software. Despite restoration works carried out in 2004, the Las Cuevas complex can still be regarded as hotspot of mercury contamination, with large anomalies above $800 \mathrm{\mu g} \mathrm{g}^{-1} \mathrm{Hg}$ (soils) and $300 \mathrm{ng} \mathrm{Hg} \mathrm{m}^{-3}$ (air). In the case of soils, high, and persistent concentrations above $26 \mu \mathrm{g} \mathrm{g}^{-1} \mathrm{Hg}$ extend well beyond the complex perimeter for more than $2 \mathrm{~km}$. These concentrations are about three orders of magnitude above world baselines. The same applies to mercury in air, with high concentrations above $300 \mathrm{ng} \mathrm{Hg} \mathrm{m}^{-3}$ inside the perimeter, which nonetheless fade away in a few hundred meters. Air contamination modelling (Hg gas) predicts formation of a NW-SE oriented narrow plume extending for a few hundred meters from the complex perimeter. The geographic isolation of Las Cuevas and its mining past make the complex an ideal site for mercury stocking. The only potential environmental hazards are the raising of livestock only a few hundred meters away from the complex and flash floods.
\end{abstract}

(c) 2010 Elsevier B.V. All rights reserved.

\section{Introduction}

In January 2005 the European Commission adopted a mercury strategy with the aim of phasing out this toxic metal (European Union, 2005). The strategy stated that surplus mercury should be safely stored or disposed of. As early as in 1992 the European Union (EU) launched LIFE (the Financial Instrument for the Environment). LIFE contributes to the implementation, development and enhancement of environmental policies and legislations as well as the integration of the environment into the other EU policies. LIFE also supports the development of new solutions to environmental problems facing the EU. In particular, the objective of the European Union authorities is to decide whatever the storage should be: temporal as metallic mercury, or definitive with mercury transformed to an inert form or species. The third 2006 LIFEEnvironment preparatory project was MERSADE (an acronym for mercury safe deposit), with design, construction and validation of a prototype installation for a temporal safe deposit of surplus metallic (liquid) mercury from European industry (LIFE06 PREP/E/000003) (European Union, 2006). From a pragmatic point of view, if a safe

\footnotetext{
* Corresponding author.

E-mail address: pablo.higueras@uclm.es (P. Higueras).
}

deposit of mercury had to be built within the EU, it seemed only logical to choose the Almadén district (Spain) as the most adequate site because of the following two reasons: 1 ) decades if not centuries of expertise on mercury handling; and 2) abandoned mining complexes that could be reutilized for different purposes. In this respect, the Almadén mining district (Fig. 1A) constitutes the world's largest natural concentration of this element (e.g., Hylander and Meili, 2003; Higueras et al., 2003, 2006). The district extends throughout an area of about $300 \mathrm{~km}^{2}$ in central Spain, and has produced one third of the total world production of this chemical element (Hernández et al., 1999). The district includes a series of mercury ore deposits having in common a rather simple mineral paragenesis, including dominant cinnabar ( $\mathrm{HgS})$ and minor pyrite $\left(\mathrm{FeS}_{2}\right)$. The mercury ore has been extracted from several mines (underground and open pit operations), including the world famous Almadén mine, El Entredicho, Nueva Concepción, Vieja Concepción, and Las Cuevas. The main mine of the district (Almadén), has been active from Roman times to present day, with almost no interruptions, except by those caused by mining disasters (floods, and fires), or external factors such as wars. At present the Almadén mine serves as a theme park (Parque Minero de Almadén) that attracts visitors interested in the mining past of the region. On the other hand, the mining complex of Las Cuevas (e.g., Higueras et al., 1999) (Fig. 1B) was chosen as the most suitable site to base the MERSADE project because of 

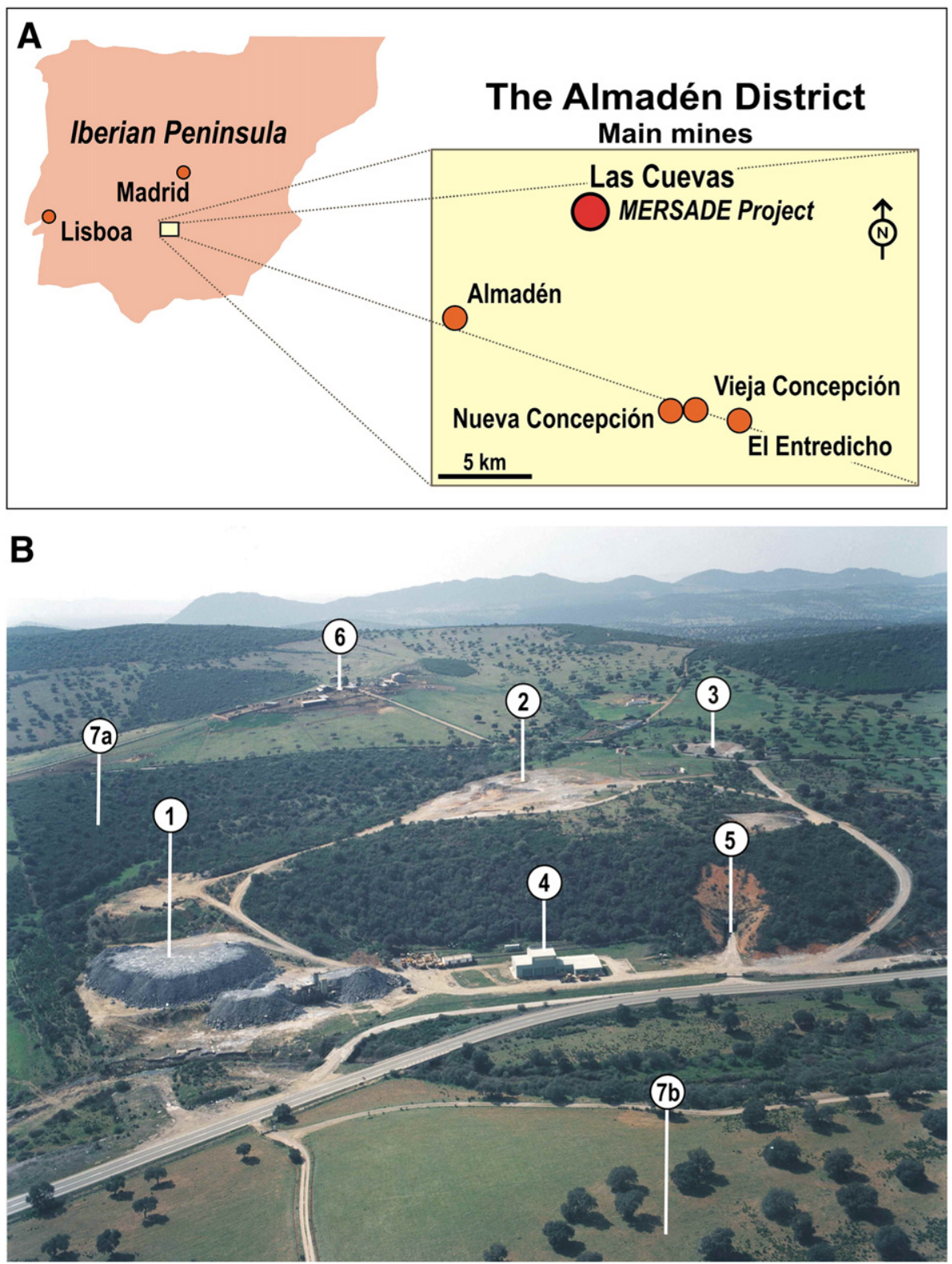

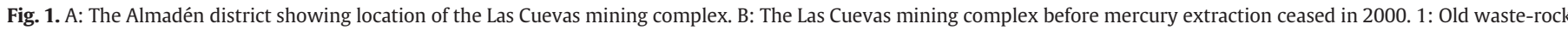

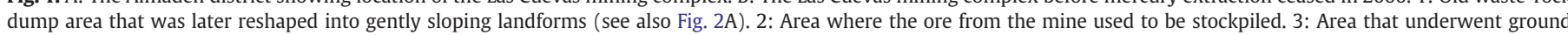

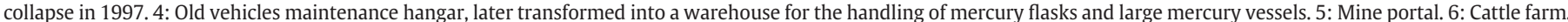
7a: Evergreen oak (Quercus rotundifolia) forest (encinar). 7b: The dehesa landscape.

the following reasons: 1 ) the site had already been subjected to land reclamation works; 2 ) Las Cuevas is well connected to the main Spanish road network; and last but not least, 3 ) different from the Almadén mine and other mining complexes from the district, the Las Cuevas complex is far away from populated areas. A baseline study on mercury distribution in soils and atmosphere in and around the Las Cuevas complex follows.

\section{Material and methods}

We studied mercury concentrations in soils and atmosphere with the use of two LUMEX RA-915+ analyzers. The analytical procedure is based on Zeeman atomic absorption spectrometry with high frequency modulation of light polarization (ZAAS-HFM) (Sholupov and Ganeyev 1995). The instrument allows determination of $\mathrm{Hg}$ in air directly with an ultra low detection limit in real time. This detection limit is governed by shot noise and equals $2 \mathrm{ng} \mathrm{m}^{-3}$ (average measuring time: $5 \mathrm{~s}$ ) and $0.3 \mathrm{ng} \mathrm{m}^{-3}$ (average measuring time: $30 \mathrm{~s}$ ) for mercury determination in air. The dynamic range of the instrument covers 4 orders of magnitude $\left(2-22,000 \mathrm{ng} \mathrm{m}^{-3}\right)$. On the other hand, the RP-91C (pyrolysis) attachment provides the capacity to measure $\mathrm{Hg}$ in solid samples. This attachment was used for the analyses of soils at the laboratories of the Almadén School of Mines (ASM). As a first step, the sample is vaporized and the $\mathrm{Hg}$ compounds partly decomposed. This is followed by heating to $800^{\circ} \mathrm{C}$, at which point the $\mathrm{Hg}$ compounds become fully decomposed, whereas organic compounds and carbon particles are catalytically transformed to carbon dioxide and water. Quality control at the ASM laboratory is done by analyzing duplicate samples to check precision, whereas accuracy is obtained by using the certified standard: NIST SRM $2710\left(32.6 \mu \mathrm{g} \mathrm{g}^{-1} \mathrm{Hg}\right)$, in this case: $98.65 \%$ (10 runs). Detection limit for total $\mathrm{Hg}$ is $0.5 \mu \mathrm{g} \mathrm{kg}-1$. Given that the topsoil is the most important part of the soil profile for degradation control (FAO, 1998), we concentrated our efforts on this superior horizon ( 5 to $30 \mathrm{~cm}$ in this sampling), roughly coinciding with the A soil horizon in the encinar forest (see 7a and 7b in Fig. 1B). The first five 
centimetres of soils are not sampled because of the continuous interchange between $\mathrm{Hg}$ atmosphere $\leftrightarrow \mathrm{Hg}$ soil at the soil surface (e.g., Scholtz et al., 2003), which can be particularly important in highly contaminated areas of the Almadén district. The soil single (bulk) samples $(\sim 1.5 \mathrm{~kg})$ were stored in plastic bags, and sieved at the Almadén School of Mines (ASM) laboratory below $2 \mathrm{~mm}$. Meteorological control was carried out using a weather station installed for the purposes of this study in the area of the facility, located $100 \mathrm{~m}$ west of the main buildings. The station (a DAVIS brand Vantage Pro2 Model) was installed at the site in February 2007 and consists of a control unit, located within the offices of the facility, in addition to a measuring unit which supports the sensors. Both units are connected by radio frequency. To monitor mercury concentration in air we established 64 measuring stations in and around Las Cuevas. To predict concentrations of mercury in air we used the ISC-AERMOD program (Lakes Environmental Software), which incorporates in a single interface three subprograms: ISCST3 (Gaussian distribution), ISC-PRIME (complex algorithms) and AERMOD (plume dispersion model). These are plume dispersion models that were developed for the U.S. Environmental Protection Agency (USEPA) to support regulatory air modelling programs. The models were specifically developed to simulate air pollution resulting from emissions from industrial sources and simulate the impact of a contaminating source such as emissions from mineral dumps, contaminated soils, etc. (e.g., Orloff et al., 2006). The models use meteorological data averaged over 1 -h periods of time to estimate 1h steady-state concentrations of air contaminants.

\subsection{The Las Cuevas mining complex site}

The mining complex (Fig. 1B) is located in front of the CM-415 road, within a landscape characterized by hills with gentle slopes of 4 to $16 \%$ that define a small valley, along which the Los Alamos stream flows (Fig. 1B). The area has a Mediterranean climate with hot summers and cold winters, with average annual precipitations in the order of $400 \mathrm{~mm}$. Average temperatures range from $1-8{ }^{\circ} \mathrm{C}$ in January to $17-31{ }^{\circ} \mathrm{C}$ in July. The vegetation around the mine complex is characterized by patches of evergreen oak (Quercus rotundifolia) forest (encinar), within a landscape dominated by the so-called dehesa: the typical man-modified landscape from central Spain, in which the initial encinar is reduced to isolated groups of trees in a landscape dominated by perennial grasses (Fig. 1B).

The Las Cuevas underground mine was operated during the 1980s and 1990s by the mining company MAYASA. With the mine closure and cessation of the activity in February 2000, a plan for permanent abandonment and environmental restoration of the affected land was presented. By the end of that year, the works started with the regeneration of the area that had been occupied by the large old waste-rock dump, the area affected by ground collapse, and eventually in 2003 on some other abandoned waste-rock dumps (Fig. 2A). In 2004 the company's stock of metallic mercury was transferred to Las Cuevas from the Almadén mining complex. To accommodate this mercury the old vehicle maintenance hangar was transformed into a warehouse for the handling of mercury flasks (34.5 kg Hg) and large mercury vessels (Fig. 2B). A safety container (in case of accidental spills) was built and six stainless steel storage tanks for liquid mercury were installed on top of it. So far no emissions of mercury from the tanks have been detected. However, the handling of flaks and vessels at old vehicle maintenance hangar results in discrete incidents leading to the accidental losses of liquid mercury. Given that liquid mercury is a highly persistent pollutant, difficult to eradicate from contaminated surfaces, this sector is a net source of gaseous mercury.

\section{Results}

Mercury concentrations in soils and air (Fig. 2C, D) are remarkably above baselines from areas no subjected to industrial activities related to the extraction, processing or use of this global pollutant, although the results are well within the ranges for the Almadén district and other mercury mining sites (Table 1 ). As expected the highest concentrations of mercury in soils and air are located inside the Las Cuevas complex perimeter. These are related to the previous sites of mineral stockpiling, waste-rock emplacement, and present activities involving handling of mercury vessels near to the main building of the complex. However, concentration in soils above $51 \mu \mathrm{g} \mathrm{g}^{-1} \mathrm{Hg}$, that is, more than three orders of magnitude above world baseline figures (0.01 to $0.03 \mu \mathrm{gg}^{-1} \mathrm{Hg}$; Senesi et al., 1999) (Table 1), extend southward well beyond the complex (Fig. 2C). Similar results were obtained for mercury in air, although the main anomaly rapidly fades away beyond a few hundred meters (Fig. 2D). The results from plume modelling using the program ISC-AERMOD are discussed in the following section.

\section{Discussion}

Photolysis of inorganic $\mathrm{Hg}^{2+}$ to $\mathrm{Hg}^{0}$ at the soil surface contributes significantly to the emission of gaseous mercury to the atmosphere (Scholtz et al., 2003). In fact, even if part of the mercury in the soil becomes bound to an organic or inorganic matrix, the element is eventually released by photo-reduction (Gustin et al., 2002), thus further contributing to the atmospheric pool. A quick check on the validity of this assumption may be provided by the analyses of soil samples from Las Cuevas, which yield results in the range of 0.75$200 \mu \mathrm{g} \mathrm{g}{ }^{-1} \mathrm{Hg}$. These results may indicate that although part of the soil's mercury escapes to the atmosphere, a substantial portion remains attached. Alternatively, it is likely that an important part of the mercury indeed escapes, but since new mercury becomes continuously adsorbed to the soil fractions (either by aerial deposition or from emissions of shallow buried contaminated sources), a permanent stock forms (e.g., Higueras et al., 2004). On the other hand, as shown by the soil survey (Fig. 2C), contamination by mercury is hardly a case restricted to the Las Cuevas mining complex, because it extends far beyond the complex premises for hundreds, even thousands of meters. In this respect, the soils from the Almadén district have anomalous contents of mercury (Higueras et al., 2003, 2006), which is not surprising if we take into account two major facts: 1 ) the area was subjected to major submarine hydrothermal processes during Silurian time (Higueras et al., 2005), which must have had a widespread impact on the regional geochemical background; and 2) the district has been mined for mercury since Roman times. Thus, the least we would expect is widespread contamination by mercury from natural and anthropic sources. However, given that the anomaly is centred at the Las Cuevas complex and particularly related to the pre-restoration site of old mineral dumps, one may argue that the source is essentially anthropic.

Modelling of mercury air emissions with program ISC-AERMOD shows that whatever the many interactions that exist between soils, mineral dumps and the handling of mercury vessels, the main impact seems to be restricted to a relatively small area surrounding the Las Cuevas complex (Fig. 2E1-E3). When the program was loaded with mercury emission, meteorological data (temperature, solar radiation, direction and speed of winds, rain precipitation, and light hours) and soil use data, high concentrations of mercury (above $1000 \mathrm{ng} \mathrm{Hg} \mathrm{m}^{-3}$ ) were only predicted for a very short period of time ( $1 \mathrm{~h}$ ) (Fig. 2E1). As the time factor increases to $24 \mathrm{~h}$ (Fig. 2E2) and up to a period of 11 months (February to December 2007) (Fig. 2E3), there is a remarkable decrease in the plume size, which adopts a NW-SE elongated shape that is strongly controlled by the dominant winds. This comes out as a consequence of the progressive influence of winds in the model, which dilute the plume thus lowering the concentrations. Venkatram et al. (2004) have shown that although the algorithm that accounts for upwind meandering has already been integrated into AERMOD, the PRIME algorithm neglects wind meandering (crucial in area with variable topography such as Las Cuevas) and overestimates pollutant 

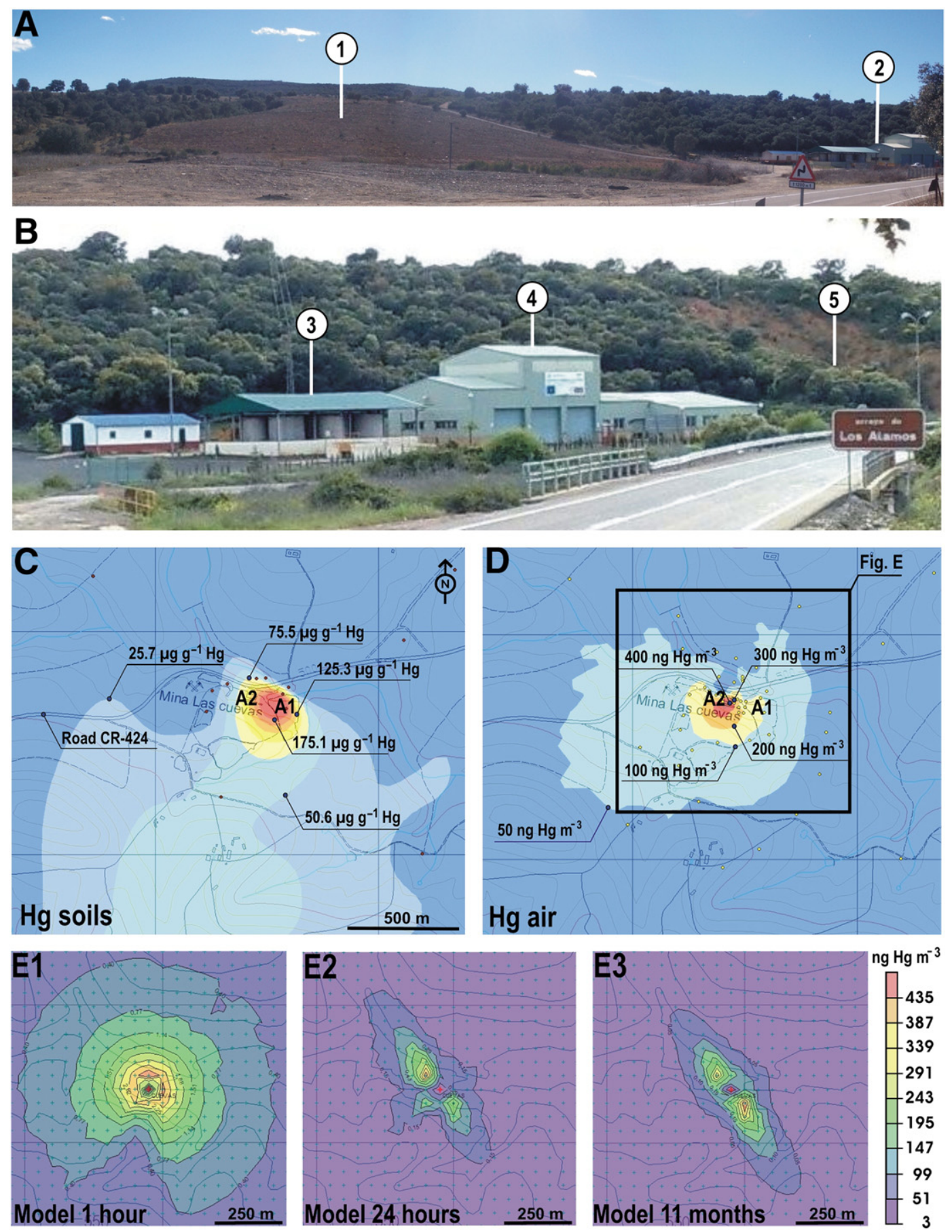

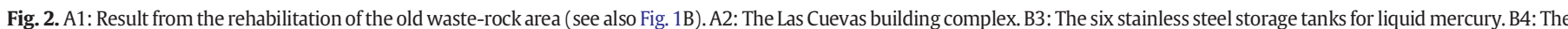

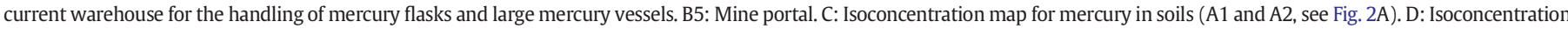

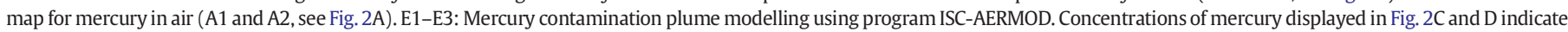
the values (in $\mu \mathrm{g} \mathrm{g}^{-1}$ and $\mathrm{ng} \mathrm{m}^{-3}$ respectively) of plotted constant-concentration contour lines.

concentrations in the near-field modelling, that is, in the prediction of physical mixing processes involving mass advection and diffusion. If this is correct, then it is likely that long-term mercury air contamination from Las Cuevas might be even less important than anticipated.

\section{Conclusions}

From the strict perspective of the MERSADE project goals, the selection of the Las Cuevas site has several pros and few cons. On one side, the area already has higher than normal mercury concentrations (soils and air), and despite the 2004 restoration works, the soils still emit mercury to the air. Thus, the safe stocking of mercury in tanks designed on the basis of the up-to-date tested ones, should not pose further hazards to the area. Besides, as stated above, there are no towns in the vicinity (the nearest town is $9 \mathrm{~km}$ away: Almadén) and no agricultural practices are recorded in the area so the risk for human health is reduced to a minimum. Furthermore, our model for $\mathrm{Hg}$ gas dispersion indicates that the resulting plume fades away in a few hundred meters (Fig. 2E1-E3). On the other hand, natural hazards such as destructive earthquakes are unheard of; however, the area 
Table 1

Mercury in soils and air from Las Cuevas, other mining sites, and world baselines.

\begin{tabular}{|c|c|c|c|c|c|}
\hline Locality & Number of samples & Range & Mean & Standard deviation & Reference \\
\hline \multicolumn{6}{|l|}{ Mercury in soils (data in $\mu g g^{-1}$ ) } \\
\hline Las Cuevas mining complex & 24 & $0.75-200$ & 24.8 & 51.8 & This work \\
\hline Almadén district & 67 & 6-8889 & 604.1 & 1798.5 & Higueras et al. (2003) \\
\hline Mieres mining sites (northern Spain) & & $1.7-2224$ & & & Loredo et al. (1999) \\
\hline Andacollo mining district (Chile) & & $2.5-47$ & & & Higueras et al. (2004) \\
\hline Uncontaminated soils (baseline) & & $0.01-0.03$ & & & Senesi et al. (1999) \\
\hline \multicolumn{6}{|c|}{ Atmospheric mercury (data in $\mathrm{ng} \mathrm{Hg} \mathrm{m}^{-3}$ ) } \\
\hline Las Cuevas mining complex & 930 & $2-779$ & $94-6$ & 135.6 & This work \\
\hline Almadén district (June 2003) & 3760 & $2-6892$ & 195.7 & 514.2 & Higueras et al. (2006) \\
\hline El Entredicho mine (June 2003) & 984 & $2-3111$ & 291.3 & 567.6 & Higueras et al. (2006) \\
\hline Mediterranean basin & & $2-3$ & & & Wängberg et al. (2001) \\
\hline Northern Europe & & $1.8-2$ & & & Wängberg et al. (2001) \\
\hline Canada & & $1.3-1.8$ & & & Kellerhals et al. (2003) \\
\hline
\end{tabular}

(as for the rest of central and southern Spain) can be subjected to intense rains and therefore to flash flood phenomena, such as those observed during the nearly catastrophic 2009-2010 winter. In this respect, despite these highly adverse, extremely anomalous meteorological conditions, the mercury stocking area remained safe.

\section{Acknowledgements}

This study has been funded by the European LIFE-Environment programme through project MERSADE (LIFE06 ENV/ES/PREP/03), as well as by the Spanish Ministry of Science and Innovation through Projects CTM2006-13091-C02-01 and CGL2009-13171-C03-01, and by Castilla-La Mancha regional government "Consejería de Educación" Projects CTM2006-13091-C02-01 and PII109-0142-4389. The manuscript benefitted from the comments of two anonymous reviewers and Executive Editor John G. Farmer.

\section{References}

European Union. Community strategy concerning mercury. Brussels: Commission of the European Communities; 2005. 11 pp. http://ec.europa.eu/environment/ chemicals/mercury/pdf/com_2005_0020_en.pdf.

European Union. LIFE news. LIFE unit. Directorate General Environment, European Commission; 2006. $\mathrm{N}^{\circ} 11 / 06$, November, http://81.188.27.167/environment/life/ news/lifeflash/lifenews11_06.htm.

FAO. Topsoil characterization for sustainable land management. Rome: Food and Agriculture Organization of the United Nations; 1998. 74 pp. ftp://ftp.fao.org/agl/ agll/docs/topsoil.pdf.

Gustin MS, Biester H, Kim CS. Investigation of the light-enhanced emission of mercury from naturally enriched substrates. Atmos Environ 2002;36:3241-54.

Hernández A, Jébrak M, Higueras P, Oyarzun R, Morata D, Munhá J. The Almadén mercury mining district, Spain. Min Deposita 1999;1999(34):539-48.
Higueras P, Oyarzun R, Lunar R, Sierra J, Parras J. The Las Cuevas deposit, Almadén district (Spain): an unusual case of deep-seated advanced argillic alteration related to mercury mineralization. Min Deposita 1999;34:211-4.

Higueras P, Oyarzun R, Biester H, Lillo J, Lorenzo S. A first insight into mercury distribution and speciation in the Almadén mining district, Spain. J Geochem Explor 2003;80:95-104

Higueras P, Oyarzun R, Oyarzun J, Maturana H, Lillo J, Morata D. Environmental assessment of copper-gold-mercury mining in the Andacollo and Punitaqui districts, northern Chile. Appl Geochem 2004;19:1855-64.

Higueras P, Munha J, Oyarzun R, Tassinari CCG, Ruiz IR. First lead isotopic data for cinnabar in the Almadén district (Spain): implications for the genesis of the mercury deposits. Min Deposita 2005;40:115-22.

Higueras P, Oyarzun R, Lillo J, Sánchez Hernández JC, Molina JA, Esbrí JM, et al. The Almadén district (Spain): anatomy of one of the world's largest Hg-contaminated sites. Sci Total Env 2006;356:112-24.

Hylander LD, Meili M. 500 years of mercury production: global annual inventory by region until 2000 and associated emissions. Sci Total Env 2003;304:13-27.

Kellerhals M, Beauchamp S, Belzer W, Blanchard P, Froude F, Harvey B, et al. Temporal and spatial variability of total gaseous mercury in Canada: results from the Canadian Atmospheric Mercury Measurement Network (CAMnet). Atmos Env 2003;37:1003-11.

Loredo J, Ordóñez A, Gallego JR, Baldo C, García-Iglesias J. Geochemical characterization of mercury mining spoil heaps in the area of Mieres (Asturias, northern Spain). J Geochem Explor 1999;67:377-90.

Orloff KG, Kaplan B, Kowalski P. Hydrogen cyanide in ambient air near a gold heap leach field: measured vs. modelled concentrations. Atmos Env 2006;40:3022-9.

Scholtz MT, Van Heyst BJ, Schroeder WH. Modelling of mercury emissions from background soils. Sci Total Environ 2003;304:185-207.

Senesi GS, Baldassare G, Senesi N, Radina B. Trace element inputs into soils by anthropogenic activities and implications for human health. Chemosphere 1999;39:343-77.

Sholupov SE, Ganeyev AA. Zeeman absorption spectrometry using high frequency modulated light polarization. Spectrochimica Acta 1995;50B:1227-38.

Venkatram A, Isakov V, Yuan J, Pankratz D. Modeling dispersion at distances of meters from urban sources. Atmos Env 2004;38:4633-41.

Wängberg I, Munthe J, Pirrone N, Iverfeldt A, Bahlman E, Costa P, et al. Atmospheric mercury distribution in northern Europe and in the Mediterranean region. Atmos Env 2001;35:3019-25. 